\title{
Penentuan Indeks Pencemaran Air dan Daya Tampung Beban Pencemaran Menggunakan Software QUAL2Kw (Studi Kasus Sungai Brantas Kota Malang)
}

\author{
Novia Lusiana ${ }^{1}$ \\ Program Studi Teknik Lingkungan, Fakultas Teknologi Pertanian \\ Universitas Brawijaya, Malang, Indonesia
}

\section{Akhmad Adi Sulianto}

Program Studi Teknik Lingkungan, Fakultas Teknologi Pertanian Universitas Brawijaya, Malang, Indonesia

\section{Luhur Akbar Devianto}

Program Studi Teknik Lingkungan, Fakultas Teknologi Pertanian Universitas Brawijaya, Malang, Indonesia

\section{Septyana Sabina}

Program Studi Teknik Lingkungan, Fakultas Teknologi Pertanian Universitas Brawijaya, Malang, Indonesia

Artikel Masuk : 18 Maret 2020

Artikel Diterima : 29 Agustus 2020

Tersedia Online : 31 Agustus 2020

\begin{abstract}
Abstrak: Perkembangan kawasan Daerah Aliran Sungai (DAS) Brantas Hulu Malang yang cukup pesat sejak tahun 2000 dari segi jumlah penduduk dan industri yang tumbuh di sekitarnya mengakibatkan peningkatan dalam penggunaan air sungai sekaligus peningkatan pencemaran terutama pencemaran organik. Faktor yang paling memengaruhi penurunan kualitas air sungai di sepanjang DAS Brantas Hulu adalah banyaknya industri yang letaknya dekat dengan sungai bahkan mejadikan sungai sebagai tempat penampungan limbah. Penelitian ini bertujuan untuk menilai kualitas air Sungai Brantas melalui penentuan pola kualitas air menggunakan model QUAL2Kw serta menentukan tingkat pencemaran Sungai Brantas melalui indeks pencemar dan penentuan daya tampung beban pencemaran. Metode yang digunakan adalah deskripsi kuantitatif dengan mendeksripsikan tingkat pencemaran kualitas air sungai Brantas dan menghitung beban pencemaran yang masih dapat diterima oleh Sungai Brantas. Hasil penelitian yang diperoleh adalah dari dua belas lokasi sampling terdapat sepuluh lokasi sampling yang memiliki status pencemaran ringan dan dua lokasi sampling dengan status pencemaran sedang. Konsentrasi pencemaran yang banyak diterima oleh Sungai Brantas Kota Malang adalah BOD, Nitrat, Ammonia dan Phosphat. Simulasi menggunakan model QUAL2Kw memiliki tingkat kesalahan rata-rata sebesar 10,7\% dari data hasil pengukuran.
\end{abstract}

\footnotetext{
${ }^{1}$ Korespondensi Penulis: Program Studi Teknik Lingkungan, Fakultas Teknologi Pertanian Universitas Brawijaya, Malang, Indonesia

Email: novialusiana@ub.ac.id
} 
Kata Kunci: beban pencemar; kualitas air; QUAL2Kw

\begin{abstract}
Starting in 2000, the growth of population and industries sector rapidly increased in Brantas Hulu's river. This phenomenon brought environmental issues since most of industries dispose of their waste including organic-based pollution to the surrounding river. It contaminates the river and lowers the water quality. Minimum assessment on water contamination in Brantas River attracts the research on the area. The study aims to assess water quality on Brantas River based on several parameters: water quality pattern using QUAL2KW model, determine of pollution level using pollutant index and pollution load capacity. The research relied on a quantitative description by measuring pollution level and calculating acceptable pollution load. The result shows that 10 from 12 sampling areas produced low pollution levels, while the others are moderate level of pollution. The most pollutant found in the Brantas River were BOD, nitrate, ammonia and phosphate. Simulation results from QUAL2KW model accounted for $10.7 \%$ of error rate.
\end{abstract}

Keywords: pollutant load; QUAL2Kw; water quality

\title{
Pendahuluan
}

Industrialisasi merupakan salah satu ancaman utama bagi lingkungan hidup karena industri akan menghasilkan masalah polutan dan pencemaran. Sisa hasil dari kegiatan industri menyebabkan adanya pencemaran lingkungan apabila dalam pengolahan limbahnya tidak menaati prosedur-prosedur yang telah ditetapkan. Faktor yang paling mempengaruhi penurunan kualitas air sungai di kawasan Daerah Aliran Sungai (DAS) Brantas Hulu adalah banyaknya industri yang letaknya dekat dengan sungai bahkan mejadikan sungai sebagai tempat penampungan limbah (Yetti, Soedharma, \& Hariyadi, 2011). Pada tahun 2015 tercatat sebanyak 138 industri besar dan sedang di Kota Malang dan pada tahun 2017 tercatat sebanyak 2.685 industri besar dan sedang di Kota Malang (BPS Kota Malang, 2018). Kegiatan pabrik mengeluarkan bahan buangan dalam bentuk cair, gas dan padatan yang dapat menganggu kelestarian lingkungan jika belum diolah sebelum masuk ke lingkungan lain. Menurut Samudro, Agustiningsih, \& Sasongko (2012), dengan adanya peningkatan kegiatan industri dan aktivitas domestik akan mempengaruhi dan memberikan sampak terhadap kondisi kualitas air sungai terutama aktivitas domestik yang memberikan masukan konsentrasi Biochemical oxygen demand (BOD) terbesar ke badan sungai.

Kepadatan penduduk Kota Malang yang meningkat setiap tahunnya dapat mempengaruhi kualitas dari Sungai Brantas. Kota Malang terdapat pada ketinggian 399$662,5 \mathrm{~m}$ di atas permukaan laut dan memiliki luas sekitar $124.400 \mathrm{~km}^{2}$ dengan jumlah penduduk sekitar 800.000 warga pada tahun 2018. Kepadatan penduduk Kota Malang dapat mencapai 5.000 hingga 12.000 jiwa per $\mathrm{km}^{2}$ dengan pertumbuhan sebesar 3,9\% pertahun (Yuliati, 2013). Apabila terjadi penurunan kualitas air di sepanjang sungai ini tentunya area yang berdampak adalah Kelurahan Sumbersari dengan jumlah penduduk 18.405 jiwa, Kelurahan Dinoyo dengan jumlah penduduk 17.168 jiwa, Kelurahan Tlogomas dengan jumlah penduduk 19.826 jiwa, Kelurahan Sukun dengan jumlah penduduk 9.041 jiwa dan Kelurahan Kedungkandang dengan jumlah penduduk 17.513 jiwa. Total jumlah masyarakat yang terdampak dengan adanya penurunan kualitas air Sungai Brantas Kota Malang sebesar 81.953 jiwa atau 9.4\% dari total masyarakat Kota Malang.

Berdasarkan kondisi tersebut perlu dilakukan upaya monitoring kondisi kualitas air untuk menentukan jumlah beban pencemaran dan status pencemaran di Sungai Brantas Kota Malang. Upaya penilaian kualitas air sungai sudah banyak dilakukan namun kendala yang sering ditemui adalah perlunya jumlah pengambilan sampel air untuk mendapatkan hasil yang representatif dan adanya perangkat yang mampu mensimulasikan penurunan 
kualitas air dengan hasil yang representatif namun cukup memerlukan data sampling yang relatif sedikit. Penggunaan model yang sering digunakan untuk perkiraan kualitas air dan beban pencemaran adalah metode neraca massa, metode Streeter-Phelps, model Qual2E yang dikembangkan menjadi model QUAL2Kw. Keunggulan menggunakan program QUAL2Kw adalah dapat melakukan simulasi sungai dalam bentuk satu dimensi dengan aliran berupa aliran tidak seragam (non uniform) dan akan stabil pada skala waktu mensimulasikan beban masuk dan keluar dari sumber pencemar (Damanik, Janianton; Weber, 2006).

Penelitian tentang daya tampung beban pencemaran dengan metode QUAL2Kw telah banyak dilakukan salah satunya dilakukan oleh Arief, Haribowo, \& Yuliani (2017) dengan metode dan sungai yang sama tetapi hanya meliputi Ruas Temas-Dadaprejo Kota Batu. Fajaruddin, Sholichin, \& Prayogo (2018) dengan metode dan sungai yang sama namun penelitian hanya sebatas dari sumber pencemar point source (domestik dan industri), sedangkan pada penelitian ini sumber pencemar yang digunakan terdiri dari point source (industri dan domestik) serta nonpoint source (aktivitas pertanian). Penelitian ini bertujuan untuk menilai kualitas air Sungai Brantas melalui penentuan pola kualitas air menggunakan model QUAL2Kw serta tingkat pencemaran Sungai Brantas melalui indeks pencemar dan penentuan daya tampung beban pencemaran.

\section{Metode Penelitian}

\section{Lokasi dan Waktu Penelitian}

Penelitian dilaksanakan di Sungai Brantas yang melewati Kota Malang, dengan pembagian sampel berdasarkan sumber pencemar (point source dan nonpoint source) yang masuk ke Sungai Brantas Kota Malang. Terdapat beberapa jenis sumber pencemar di sepanjang Sungai Brantas Kota Malang yaitu berupa limbah domestik, limbah pertanian, limbah rumah sakit dan limbah industri. Pemilihan sumber pencemar didasarkan atas kategori kegiatan yang memiliki kontribusi besar dalam mengahasilkan jumlah limbah cair. Berdasarkan identifikasi jenis kegiatan di Kota Malang, maka penentuan jenis kegiatan yang dipilih sebagai sumber pencemar meliputi: (1) Rumah Sakit dengan alasan limbah cair yang dihasilkan relatif memiliki konsentrasi berbahaya; (2) kegiatan industri, mengingat banyaknya (2.865 industri besar dan sedang) industri di Kota Malang, maka untuk mereduksi jumlah sumber pencemar maka hanya industri yang termasuk dalam kategori industri besar yang memiliki jumlah tenaga kerja lebih dari 100 orang; (3) pemukiman, area yang dipilih adalah area perbatasan Kecamatan Sukun (area berpenduduk padat yang di dalamnya terdapat aktivitas mall, pasar dan perkantoran) dan Kedungkandang untuk menilai peran limbah domestik dalam penurunan kualitas air Sungai Metro; (4) pertanian, area yang dipilih yang masih memiliki aktivitas pertanian yaitu di Kecamatan Kedungkandang. Tabel 1 merupakan daftar industri dan rumah sakit yang digunakan sebagai lokasi sumber pencemar pada penelitian ini dan Gambar 1 merupakan sebaran lokasi sumber pencemar.

\section{Penentuan Titik Sampel}

Pertimbangan - pertimbangan yang digunakan dalam pengambilan sampel air sungai menurut Mahmud (2014), yaitu: (1) sumber air alamiah, yaitu lokasi yang belum pernah atau masih sedikit mengalami pencemaran; (2) sumber air tercemar, yaitu lokasi yang telah mengalami perubahan atau di bagian hilir dari sumber pencemar; dan (3) sumber air yang dimanfaatkan, yaitu lokasi penyadapan/pemanfaatan. 
Tabel 1. Lokasi Pengambilan Sampel

\begin{tabular}{clll}
\hline No & \multicolumn{1}{c}{ Nama } & \multicolumn{1}{c}{ Bidang } & \multicolumn{1}{c}{ Lokasi } \\
\hline 1 & Indana Paint & Industri Cat & Jl. Laksda Adi Sucipto No. 456, Malang \\
2 & Bronson Prima & Indutsri Makanan (Permen) & Jl. Tenaga 8, Blimbing, Malang \\
3 & HM Sampoerna & Industri Rokok & Jl. Industri Barat, 2, Malang \\
4 & Bintang Terang & Industri Plastik & Jl. Letjen S. Parman IV, Blimbing \\
5 & Nitradi Wahyu & Industri Plastik & Jl. S.priyo Sudarmo, 33, Malang \\
& Cemerlang & & \\
6 & PR AA & Industri Rokok & Jl. M. Sungkono RT 2/RW2, Malang \\
7 & Surya Sejahtera & Industri Rokok & Jl. Mayjen Sungkono, Malang \\
8 & Usaha Loka & Industri Plastik & Jl. Peltu Sujono, Malang \\
9 & Bentoel Prima & Industri Rokok & Jl. Niaga 2, Malang \\
10 & PT Gandum & Industri Rokok & Jl. Mulyosari, Malang \\
11 & PT Asia & Industri Rokok & Jl. Mulyosari 15, Malang \\
12 & PT Banyu Biru & Industri Rokok & Jl. A. R. Hakim 2, Malang \\
13 & RS UMM & Rumah Sakit & Jl. Raya Tlogomas No. 45, Malang \\
14 & RSUD Kota Malang & Rumah Sakit & Jl. Rajasa No. 27, Kedungkandang \\
15 & RS Panti Nirmala & Rumah Sakit & Jl. Kebalen Wetan No. 2-8, Malang \\
16 & RS Aisyiyah & Rumah Sakit & Jl. Sulawesi 16, Malang \\
17 & RS Panti Waluyo & Rumah Sakit & Jl. Nusakambangan No. 56, Malang \\
18 & RST Soepraoen & Rumah Sakit & Jl. Sudanco Supriadi No. 22 \\
19 & RS Syaiful Anwar & Rumah Sakit & Jl. Jaksa Agung Suprapto No. 2 \\
20 & Pemukiman & Kegiatan Domestik & Kelurahan Kotalama \\
21 & Sawah & Kegiatan Pertanian & Kelurahan Kedungkandang \\
\hline
\end{tabular}

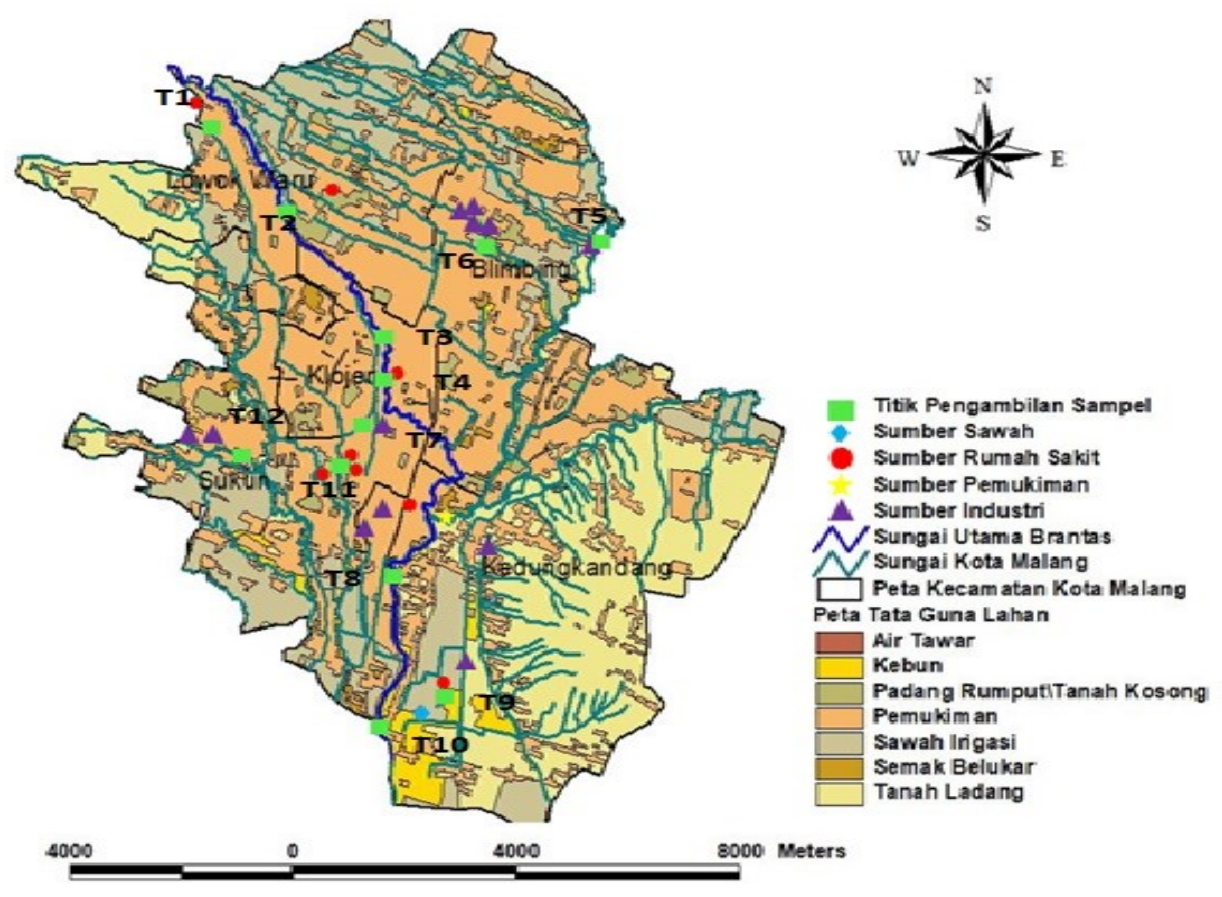

Gambar 1. Peta Titik Pengambilan Sampel Sungai Brantas Kota Malang

\section{Pengambilan Sampel}

Pengambilan sampel dilakukan sebanyak tiga kali dengan menentukan tiga titik. Hal tersebut dilakukan untuk mengetahui gambaran yang sebenarnya dari keadaan sungai. Pengambilan sampel dilakukan secara sampel sesaat (grab sampling) atau sampel diambil 
pada waktu - waktu tertentu dan sampel tersebut sudah dapat mewakili limbah atau badan air secara keseluruhan. Tata cara pengambilan sampel dapat dilakukan sebagai berikut: menyiapkan wadah sampel, membilas wadah sampel dengan air suling, menyiapkan alat pengambil sampel sesuai keadaan sumber air, membilas alat pengambil sampel, mengambil sampel sesuai titik sampling dan memasukkannya ke wadah sampel sesuai peruntukan analisis, mencatat kondisi lapangan, membuat peta lokasi, menentukan uji parameter lapangan, memberi label pada wadah sampel, melakukan pengawetan sampel sesuai peruntukan uji, mengamankan sampel dan wadah dan mencatat nama sumber air, tanggal dan jam pengambilan, keadaan cuaca, bahan pengawet yang ditambahkan, dan nama petugas.

\section{Pengujian Sampel}

Metode pengujian sampel mengikuti Standar Nasional Indonesia yang digunakan oleh Laboratorium Lingkungan milik Perum Jasa Tirta I Kota Malang, metode pengujian yang digunakan dapat ditunjukkan pada Tabel 2 .

Tabel 2. Metode Pengujian Sampel

\begin{tabular}{|c|c|c|c|}
\hline Parameter & Metode Pengujian & Parameter & Metode Pengujian \\
\hline Temperatur & QI/LKA/12 (Termometri) & $\begin{array}{l}\text { Total Suspended } \\
\text { Solid (TSS) }\end{array}$ & APHA.2540 D-2005 \\
\hline $\mathrm{pH}$ & QI/LKA/08 (Elektormetri) & Nitrat & QI/LKA/65 \\
\hline DO & QI/LKA/02 (Elektrometri) & Ammonia & APHA.4500-NH3 F-2005 \\
\hline BOD & AРНA.5210 B-1998 & Phosphat & SNI 19-2483-1991 \\
\hline Chemical & QI/LKA/19 (Spektrofotometri) & Coli Tinja & QI/LKA/53 (Tabung Ganda) \\
\hline Oxygen & & & \\
\hline Demand (COD) & & & \\
\hline
\end{tabular}

\section{Penentuan Kualitas Air}

Sesuai dengan Peraturan Gubernur Jawa Timur Nomor 61 Tahun 2010 tentang Penetapan Kelas Air pada Sungai, Sungai Brantas Kota Malang ditetapkan dalam kelas air golongan II. Pada penjelasan Peraturan Pemerintah No. 82 Tahun 2001, kelas air adalah peringkat kualitas air yang dinilai masih layak untuk dimanfaatkan bagi peruntukan tertentu. Kelas II adalah air yang peruntukannya dapat dimanfaatkan sebagai prasarana/sarana rekreasi air, pembudidayaan ikan air tawar, peternakan, irigasi, dan atau peruntukan lain yang mempersyaratkan mutu air yang sama.

Setelah didapatkan data hasil pengujian kualitas air sesuai dengan parameter yang telah ditetapkan, selanjutnya adalah perbandingan dengan Standar Baku Mutu Kualitas Air, mengacu pada PP No. 82 Tahun 2001. Pada lampiran PP No. 82 Tahun 2001 telah ditetapkan standar kualitas air kategori Kelas II yang ditunjukkan pada Tabel 3.

\section{Perhitungan Beban Pencemaran Sungai}

Pengertian beban pencemaran adalah jumlah suatu unsur pencemar yang terkandung dalam air atau limbah. Beban pencemaran maksimum adalah beban pencemaran yang diperbolehkan di suatu sungai berdasarkan peruntukannya (Kementrian Lingkungan Hidup, 2003). Perhitungan ini dimaksudkan untuk mengetahui kondisi awal sungai tanpa adanya masukan sumber pencemar. Definisi beban pencemaran erat kaitannya dengan jumlah total pencemar yang dialirkan lingkungan baik secara langsung maupun secara tidak langsung dari aktivitas perkotaan selama periode waktu tertentu. Rumus perhitungan beban pencemaran seperti yang ditampilkan pada persamaan (1), sebagai berikut: 


$$
\mathrm{BPM}=\mathrm{Q} \times \mathrm{C}_{\mathrm{BM}}
$$

Keterangan: $\mathrm{BPM}=$ Beban pencemaran maksimum (kg/hari); $\mathrm{Q}=$ Debit terukur ( $\mathrm{m}^{3} /$ detik); $\mathrm{C}_{\mathrm{BM}}=$ Konsentrasi (berdasarkan standar kelas kualitas air yang digunakan) (mg/liter).

Beban pencemaran aktual adalah beban pencemaran yang dihasilkan di suatu sungai pada saat kondisi eksisting, rumus yang digunakan dalam menghitung beban pencemaran aktual, sebagaimana ditampilkan pada persamaan (2), sebagai berikut:

$$
\mathrm{BPA}=\mathrm{Q} \times \mathrm{C}_{\mathrm{M}}
$$

Keterangan: BPA = Beban pencemaran aktual (kg/hari); $\mathrm{Q}=$ Debit terukur ( $\mathrm{m}^{3} /$ detik); $\mathrm{C}_{\mathrm{M}}=$ Konsentrasi terukur (mg/liter).

\begin{tabular}{|c|c|c|c|}
\hline Parameter & Satuan & Nilai & Keterangan \\
\hline \multicolumn{4}{|l|}{ FISIKA } \\
\hline Temperatur & ${ }^{\circ} \mathrm{C}$ & Deviasi 3 & Deviasi temperatur dari alamiahnya \\
\hline TSS & $\mathrm{mg} / \mathrm{L}$ & 1000 & \\
\hline \multicolumn{4}{|l|}{ KIMIA } \\
\hline $\mathrm{pH}$ & & $6-9$ & $\begin{array}{l}\text { Apabila secara alamiah di luar rentang tersebut, } \\
\text { maka ditentukan berdasarkan kondisi alamiah }\end{array}$ \\
\hline BOD & $\mathrm{mg} / \mathrm{L}$ & 3 & \\
\hline COD & $\mathrm{mg} / \mathrm{L}$ & 25 & \\
\hline DO & $\mathrm{mg} / \mathrm{L}$ & 4 & Angka batas minimum \\
\hline $\begin{array}{l}\text { Total Fosfat } \\
\text { sebagai P }\end{array}$ & $\mathrm{mg} / \mathrm{L}$ & 0,2 & \\
\hline $\mathrm{NO}_{3}$ sebagai $\mathrm{N}$ & $\mathrm{mg} / \mathrm{L}$ & 10 & \\
\hline $\mathrm{NH}_{3}-\mathrm{N}$ & $\mathrm{mg} / \mathrm{L}$ & $(-)$ & $\begin{array}{l}\text { Bagi Perikanan konsentrasi amonia bebas untuk } \\
\text { ikan yang peka }< \\
0,02 \mathrm{mg} / \mathrm{L} \text { sebagai } \mathrm{NH} 3\end{array}$ \\
\hline Nitrit sebagai $\mathrm{N}$ & $\mathrm{mg} / \mathrm{L}$ & 0,06 & $\begin{array}{l}\text { Bagi pengolahan air minum secara } \\
\text { konvensional, } \mathrm{NO}_{2}-\mathrm{N}<1 \mathrm{mg} / \mathrm{L}\end{array}$ \\
\hline \multicolumn{4}{|r|}{ 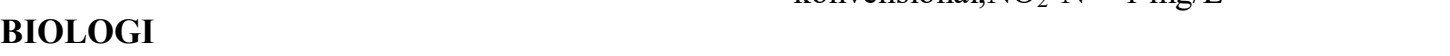 } \\
\hline Fecal Coliform & $\begin{array}{r}\mathrm{Jml} / \\
100 \mathrm{ml}\end{array}$ & 1000 & $\begin{array}{l}\text { Bagi pengolahann air minum secara } \\
\text { konvensional, fecal coliform }\end{array}$ \\
\hline Total Coliform & $\begin{array}{r}\mathrm{Jml} / \\
100 \mathrm{ml}\end{array}$ & 5000 & $\begin{array}{l}<2000 \mathrm{jml} / 100 \mathrm{~mL} \text { dan Total coliform }<10000 \\
\mathrm{jml} / 100 \mathrm{~mL}\end{array}$ \\
\hline
\end{tabular}

Tabel 3. Tabel Kiteria Mutu Air Kelas II PP No. 82 Tahun 2001

\section{Simulasi Model QUAL2KW}

Program QUAL2Kw merupakan metode yang direkomendasikan seperti yang tertera pada Keputusan Menteri Negara Lingkungan Hidup No. 110 Tahun 2003 tentang Pedoman Penetapan Daya Tampung Beban Pencemaran Air pada Sumber Air yang merupakan kembangan lanjut dari Qual2E. Model QUAL2Kw merupakan pengembangan dari Qual2E dengan menggunakan bahasa pemograman Visual Basic for Application (VBA) yang dapat dijalankan denan program Microsoft Excel (Pelletier \& Chapra, 2006).

Tahapan dalam simulasi menggunakan odel QUAL2Kw adalah instalasi program, input data pada lembar kerja karekteristik sungai, input data lembar kerja headwater yang digunakan untuk memasukkan aliran dan pemusatan dari batasan-batasan system, lembar kerja reach digunakan memasukkan informasi yang berhubungan dengan aliran hulu sungai (Reach No. 0) dan jangkauan-jangkauannya, input data lembar kerja reach rates bersifat opsional untuk memasukkan informasi terkait dengan konstanta dan parameter spesifik terhadap reach, input data lembar kerja meteorology and shading untuk memasukkan air 
temperature, wind speed dan cloud cover dan shade, input data lembar kerja rates digunakan untuk memasukkan parameter rate model dan pilihan kalibrasi otomatis opsional, input data lembar kerja light and heat digunakan untuk memasukkan informasi terkait dengan parameter-parameter pencahayaan dan panas system, input data lembar kerja point source digunakan untuk memasukkan informasi terkait dengan titik sumbersumber sistem, input data lembar kerja diffuse sources digunakan untuk memasukkan informasi terkait dengan sumber dan abstraksi persebaran sistem, running program dan diperoleh output data.

\section{Validasi Hasil Simulasi QUAL2Kw}

Validasi model digunakan untuk mengetahui kesesuaian model yang dihasilkan dengan data kualitas air yang sebelumnya diinput dalam proses pemodelan sehingga dapat digunakan untuk menjalankan skenario. Berikut adalah rumus perhitungan uji validasi menggunakan metode Chi square, sebagaimana ditampilkan pada persamaan (3).

$$
x^{2}=\sum_{r=0}^{n} \frac{(\text { Nilai Observasi }- \text { Nilai Model })^{2}}{\text { Nilai Model }}
$$

Keterangan: $\mathrm{x}^{2}$ : uji statistik rata-rata kuadrat dari simpangan; $\mathrm{n}$ : jumlah sampel; $\mathrm{r}$ : sampel ke-n. Hasil perhitungan $\mathrm{x}^{2}$ dibandingkan dengan $\mathrm{x}^{2}$ tabel pada $\alpha=0$,95. Jika $\mathrm{x}^{2}$ hitung $>\mathrm{x}^{2}$ tabel, maka model ditolak dan jika $x^{2}$ hitung $<x^{2}$ tabel, maka model diterima.

\section{Hasil dan Pembahasan}

\section{Simulasi Kualitas Air Menggunakan Model QUAL2KW}

Simulasi menggunakan program QUAL2Kw memiliki tahapan yang relatif lebih kompleks. Data input yang dibutuhkan untuk simulasi menggunakan QUAL2Kw hampir sama dengan Qual2E namun ada beberapa perbedaan satuan yang digunakan dan format dalam input data. Hasil simulasi menggunakan QUAL2Kw harus melalui kalibrasi terlebih dahulu melalui Trial and Error pada sheet Reach, Reach Rates dan Initial Condition. Berikut ini merupakan visualisasi hasil simulasi QUAL2Kw yang dapat dilihat pada Gambar 2.

Berdasarkan hasil pengukuran suhu diperoleh bahwa keseluruhan lokasi memiliki suhu yang relatif lebih tinggi dibandingkan dengan standar baku mutu dengan interval suhu antara $25.6-25.9^{\circ} \mathrm{C}$. Hal ini dikarenakan pengambilan sampel dilakukan siang hari. Temperatur air yang tinggi dalam kisaran $23-25^{\circ} \mathrm{C}$ telah terbukti meningkatkan tingkat kematian sejumlah spesies ikan (Bjornn \& Reiser, 1991; Hodgson \& Quinn, 2002; Lee \& Rinne, 1980). Lund, Caissie, Cunjak, Vijayan, \& Tufts (2002) menunjukkan suhu air musim panas yang tinggi menjadi penyebab respon goncangan panas pada salmon remaja. Selanjutnya, perubahan signifikan dalam suhu sungai diproyeksikan terjadi selama abad ini sebagai konsekuensi dari pemanasan global (Mohseni \& Stefan, 1999; Webb, 1996; Webb \& Walsh, 2004).

Berdasarkan hasil pengukuran $\mathrm{pH}$ dari 12 lokasi sampling, terdapat 11 lokasi yang nilai $\mathrm{pH}$ nya lebih dari standar baku mutu dengan batas minimal 6 dan maksimal 9. Nilai pH tertinggi berada dilokasi kedua dengan nilai $\mathrm{pH}$ sebesar 8.3 yang bersifat basa dengan lokasi sampling berada di dekat bangunan RS UNISMA. Keasaman atau alkalinitas air limbah merusak pengumpulan air limbah dan fasilitas pengolahan dan mengganggu proses pengolahan biologis (Emmanuel, Perrodin, Keck, Blanchard, \& Vermande, 2005).

Kondisi oksigen terlarut pada keseluruhan lokasi sampling menunjukkan bahwa konsentrasi DO paling rendah dengan nilai dibawah standar $4 \mathrm{mg} / \mathrm{L}$ adalah lokasi sampling 
keenam yang mendapatkan kontribusi pencemaran dari aktivitas industri rokok dan industri plastik. Konsentrasi DO untuk keseluruhan lokasi masih relatif memenuhi batas minimum konsentrasi DO.

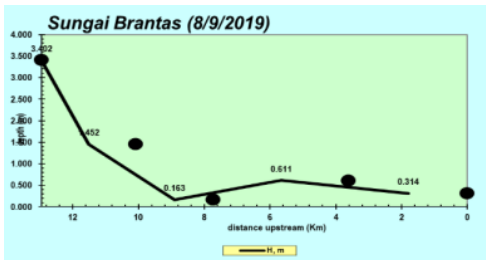

(a)

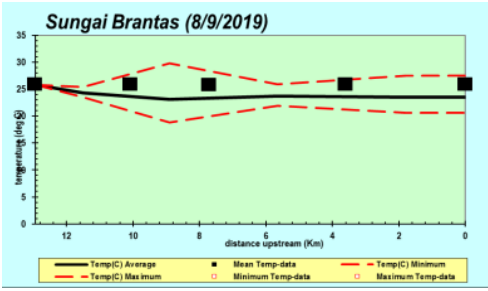

(d)

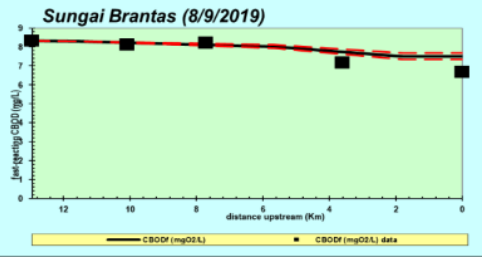

$(\mathrm{g})$

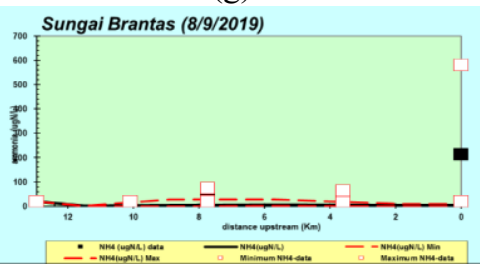

(j)

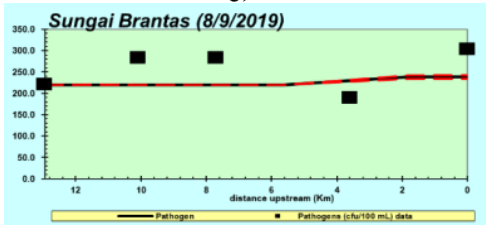

(m)

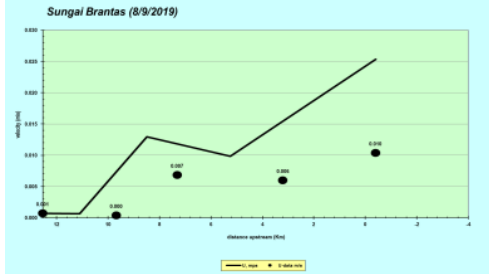

(b)

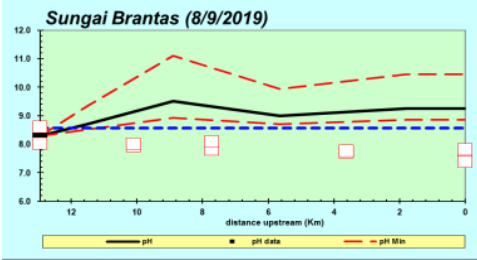

(e)

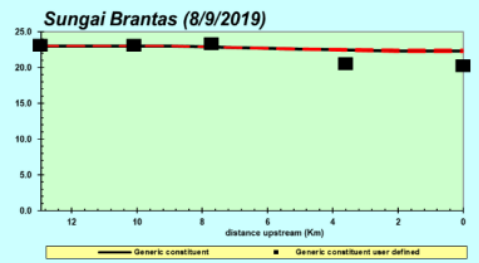

(h)

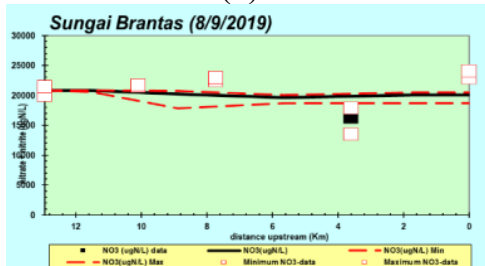

(k)

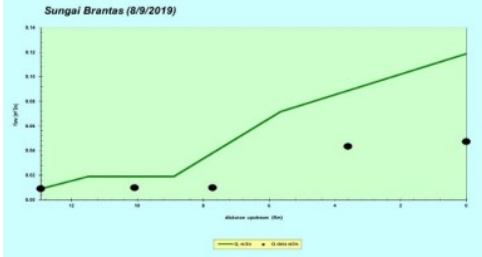

(c)

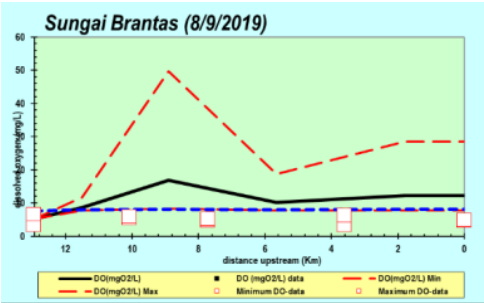

(f)

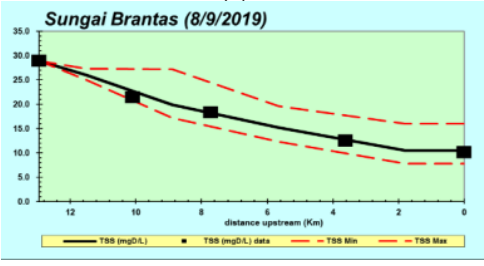

(i)

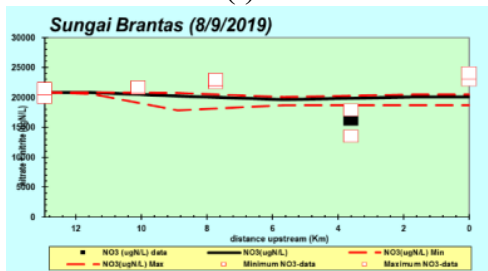

(1)

Gambar 2. Visualisasi Simulasi Kualitas Air (a) Kedalaman Sungai Lokasi Sampling; (b) Kecepatan Air Lokasi Sampling (c) Debit Air Lokasi Sampling; (d) Suhu Air pada Lokasi Sampling; (e) pH Air Sungai;

(f) Pola Konsentrasi DO; (g) Pola Konsentrasi BOD; (h) Pola Konsentrasi COD; (i) Pola Konsentrasi TSS; (j) Pola Konsentrasi NH4; (k) Pola Konsentrasi N03; (I) Pola Konsentrasi Phospat Terlarut; dan (m) Pola Konsentrasi Total Coliform

Kondisi BOD pada keduabelas lokasi sudah melampui standar baku mutu yang ditentukan. Konsentrasi BOD paling tinggi berada di lokasi sampling keenam dengan nilai $38 \mathrm{mg} / \mathrm{L}$. Hal ini dikarenakan lokasi tersebut banyak menerima jenis pencemar dari kegiatan industri dan rumah sakit. Selisih terbesar antara standar baku mutu dan konsentrasi BOD tertinggi adalah sebesar $35 \mathrm{mg} / \mathrm{L}$ dan selisih terendah adalah $4 \mathrm{mg} / \mathrm{L}$. 
Nilai BOD sungai Brantas masih relatif lebih kecil jika dibandingkan dengan penelitian Zahroh, Riani, \& Anwar (2019) BOD di Perairan Mundu untuk tahun 2015-2016 berkisar antara $16 \mathrm{mg} / \mathrm{l}-18.4 \mathrm{mg} / \mathrm{l}$. Perairan Suranenggala pada tahun 2015 berkisar antara 15.3 $\mathrm{mg} / \mathrm{l}-16.4 \mathrm{mg} / \mathrm{l}$ dan mengalami peningkatan pada tahun 2016 yaitu $31.8 \mathrm{mg} / \mathrm{l}-33.9$ $\mathrm{mg} / \mathrm{l}$. Konsentrasi COD tertinggi juga ada dilokasi ke enam dengan nilai konsentrasi COD sebesar $102 \mathrm{mg} / \mathrm{L}$ dengan selisih $77 \mathrm{mg} / \mathrm{L}$ dari standar baku mutu, sedangkan konsentrasi COD lokasi lainnya di antara nilai $19-23 \mathrm{mg} / \mathrm{L}$. Dalam beberapa referensi, rasio (COD/BOD5) diambil untuk tujuan yang sama dan merupakan dasar pemilihan proses pengolahan biologis yang tepat. Rasio rata-rata $(\mathrm{COD} / \mathrm{BOD} 5)=2.17$ dari 12 rumah sakit, rasio ini lebih rendah atau sama dengan 2,5. Namun demikian, tiga rumah sakit memiliki COD/BOD5> 2.5, H2, H7 dan H10. Analisis DO oksigen terlarut mengukur jumlah gas oksigen (O2) yang dilarutkan dalam larutan berair. Oksigen masuk ke dalam air melalui difusi dari udara di sekitarnya, melalui aerasi (gerakan cepat), dan sebagai produk limbah fotosintesis (Salem, Toumi, Kechroud, \& Allia, 2007).

Konsentrasi TSS pada keseluruhan lokasi masih dibawah standar baku mutu sehingga konsentrasi sedimen di Sungai Brantas Kota Malang masih relatif kecil. Berdasarkan hasil uji konsentrasi TSS diperoleh bahwa nilai tertinggi di lokasi sampling sembilan dengan konsentrasi TSS sebesar $49 \mathrm{mg} / \mathrm{L}$ dan selisih dengan standar baku mutu berkisar $1 \mathrm{mg} / \mathrm{L}$ sehingga diperlukan upaya pengurangan potensi penambahan sedimen yang masuk ke badan air. Konsentrasi TSS terendah berada di lokasi terakhir dengan nilai $6.267 \mathrm{mg} / \mathrm{L}$ diakibatkan sumber pencemar domestik dan industri. Besarnya konsentrasi TSS dipengaruhi oleh banyak sedikitnya lahan terbuka disekitar badan air dan besarnya limpasan permukaan yang membawa sedimen ke badan air. Berdasarkan penelitian Komang dkk, 2014 menyatakan adanya peningkatan konsentrasi TSS di sungai sebesar 30.6\%, konsentrasi BOD sebesar $42.5 \%$, konsentrasi COD sebesar 49.6\%, dan nitrat sebesar $22.7 \%$ pada kondisi air sungai setelah mendapat masukan air limbah domestik.

Konsentrasi nitrat paling tinggi berada di lokasi keduabelas sebesar $26.150 \mathrm{mg} / \mathrm{L}$. Hal ini dikarenakan terdapat pencemaran dari kegiatan pertanian sedangkan yang terendah sebesar $2.674 \mathrm{mg} / \mathrm{L}$ berada di lokasi keenam yang sumber pencemar didominasi oleh industri dan rumah sakit. Hampir keseluruhan lokasi memiliki konsentrasi nitrat lebih besar dibandingkan standar baku mutu, sehingga perlu adanya upaya pengurangan aktivitas yang berpotensi memiliki konsentrasi nitrat yang relatif tinggi. Nitrat yang terdapat dalam sumber air seperti air sumur dan sungai umumnya berasal dari pencemaran bahan-bahan kimia (pupuk urea, ZA dan lain-lain) di bagian hulu. Konsentrasi nitrat yang tinggi di perairan akan menstimulasi pertumbuhan dan perkembangan organisme di perairan apabila didukung oleh ketersediaan nutrient. Polusi sumber nonpoint yang disebabkan oleh nitrogen dari agroekosistem adalah ancaman serius bagi lingkungan air dan telah mendapat perhatian yang meningkat secara regional dan global (Spalding \& Exner, 1993; Sun et al., 2012; Wang, Gao, Li, Zhang, \& Wang, 2015). Kegiatan pertanian berkontribusi sekitar $75 \%$ dari polusi nonpoint, yang menyumbang sekitar dua pertiga dari total polusi, di Amerika Serikat (Line, Harman, Jennings, Thompson, \& Osmond, 2000). Pertanian adalah sumber utama pencemaran sungai dan air tanah di daerah pedesaan Inggris (Neal et al., 2000). Polusi nonpoint dari pertanian cenderung tidak pasti, karena tergantung pada waktu, frekuensi, dan intensitas curah hujan (Abler, 2015).

Berdasarkan hasil pengujian konsentrasi amonia terdapat empat lokasi yang memiliki konsentrasi amonia lebih tinggi dibandingkan standar baku mutu dengan nilai tertinggi berada di lokasi keenam dengan nilai $1.739 \mathrm{mg} / \mathrm{L}$. Hal ini dikarenakan banyaknya sumber pencemar lebih bervariasi dibandingkan dengan lokasi yang lain apabila dibandingkan dengan konsentrasi nitrat pada Sungai Ciliwung yang memiliki konsentrasi nitrat rata-rata di Sungai Ciliwung berada pada rentang $2.28 \mathrm{mg} / \mathrm{l}-5.66 \mathrm{mg} / \mathrm{l}$, konsentrasi nitrat sungai Brantas masih relatif kecil (Patricia, Astono, \& Hendrawan, 2018). Pada saat konsentrasi 
oksigen rendah, nitrogen berubah menjadi amonia dan saat konsentrasi oksigen tinggi nitrogen berubah menjadi nitrat. Hilangnya amonia ke atmosfer dapat meningkat dengan meningkatnya kecepatan angin dan suhu (Sammana, 2006).

\section{Validasi Hasil Simulasi QUAL2KW}

Berdasarkan hasil uji validasi x2 diperoleh bahwa keseluruhan hasil simulasi model QUAL2Kw dapat diterima dengan nilai x2 tertinggi $30.32 \%$ pada parameter DO. Hal ini disebabkan pada saat kalibrasi perubahan grafik sangat tidak significant sehingga tingkat kesalahan hasil yang diperoleh cukup besar. Kesalahan nilai x2 terendah ada pada uji simulasi parameter BOD dengan nilai 3.8\%, berbeda dengan proses kalibrasi BOD yang setiap perubahan nilai akan memberikan dampak yang significant sehingga untuk mendapatkan hasil simulasi yang hampir sama dengan hasil uji tidak terlalu susah. Ratarata perbedaan kualitas air hasil pengujian laboratorium dan hasil simulasi memiliki perbedaan sebesar $10.17 \%$. Rekapan uji validasi hasil simulasi kualitas air menggunakan model QUAL2Kw dapat dilihat pada Tabel 4.

Hasil dari penelitian Fajarudin et al., 2018 menyatakan bahwa saat melakukan kalibrasi model hidrolika, didapatkan kesalahan relatif rata-rata sebesar 4,42\% untuk debit, kesalahan relatif sebesar $11 \%$ untuk kedalaman, dan kesalahan relatif $21,16 \%$ untuk kecepatan, kemudian dilakukan kalibrasi model kualitas air yang didapatkan kesalahan relatif parameter TSS adalah sebesar 8,56\%, kesalahan relatif parameter DO adalah sebesar $7.28 \%$, kesalahan relatif parameter BOD adalah sebesar 5.32\%, kesalahan relatif parameter COD adalah sebesar $4.59 \%$, kesalahan relatif parameter Nitrat adalah sebesar $9.35 \%$, dan kesalahan relatif parameter $\mathrm{pH}$ adalah sebesar 9,32\%. Verifikasi model pada tahun 2016 menunjukkan besar kesalahan relatif sebesar $7.403 \%$.

Tabel 4. Rekapan Uji Validitas Hasil Simulasi QUAL2Kw

\begin{tabular}{|c|c|c|c|c|c|c|c|c|c|c|c|c|c|c|c|}
\hline \multirow{2}{*}{ Jarak (km) } & \multicolumn{2}{|c|}{ pH } & \multicolumn{4}{|c|}{ Temperature } & \multicolumn{3}{|c|}{ DO } & \multicolumn{3}{|c|}{ BOD } & \multicolumn{3}{|c|}{ COD } \\
\hline & OV & MR & $\mathrm{X}^{2}$ & OV & MR & $\mathrm{X}^{2}$ & OV & MR & $\mathrm{X}^{2}$ & OV & MR & $X^{2}$ & OV & MR & $\mathrm{X}^{2}$ \\
\hline 12.94 & 8.29 & 8.29 & 0 & 25.8 & 25.8 & 0.00 & 5.2 & 5.2 & 0.00 & 8.32 & 8.32 & 0.00 & 22.98 & 22.98 & 0.00 \\
\hline 10.08 & 8.7 & 7.97 & 0.06 & 24.32 & 25.87 & 0.10 & 5.9 & 5.73 & 0.00 & 8.29 & 8.11 & 0.00 & 22.98 & 22.99 & 0.00 \\
\hline 7.71 & 9.5 & 7.93 & 0.26 & 23.13 & 25.77 & 0.30 & 5.2 & 4.9 & 0.02 & 8.18 & 8.2 & 0.00 & 22.98 & 23.23 & 0.00 \\
\hline 3.6 & 9 & 7.72 & 0.18 & 23.67 & 25.8 & 0.19 & 4.5 & 4.5 & 0.00 & 8.02 & 7.15 & 0.09 & 22.61 & 20.44 & 0.21 \\
\hline 0 & 9.26 & 7.66 & 0.28 & 23.46 & 25.87 & 0.25 & 8.2 & 4.7 & 1.49 & 7.49 & 6.66 & 0.09 & 22.25 & 20.12 & 0.20 \\
\hline & \multicolumn{2}{|c|}{ Rata-rata } & 0.16 & \multicolumn{2}{|c|}{ Rata-rata } & 0.17 & \multicolumn{2}{|c|}{ Rata-rata } & 0.30 & \multicolumn{2}{|c|}{ Rata-rata } & 0.04 & \multicolumn{2}{|c|}{ Rata-rata } & 0.08 \\
\hline & \multicolumn{2}{|l|}{ Total } & 0.78 & \multicolumn{2}{|c|}{ Total } & 0.84 & \multicolumn{2}{|l|}{ Total } & 1.52 & \multicolumn{2}{|l|}{ Total } & 0.19 & Total & & 0.41 \\
\hline & \multicolumn{2}{|c|}{ Model diterima } & \multicolumn{3}{|c|}{ Model diterima } & & \multicolumn{3}{|c|}{ Model diterima } & \multicolumn{3}{|c|}{ Model diterima } & \multicolumn{3}{|c|}{ Model diterima } \\
\hline \multirow{2}{*}{ Jarak (km) } & \multicolumn{2}{|c|}{ TSS } & & \multicolumn{3}{|c|}{ Phosphate } & \multicolumn{3}{|c|}{ Nitrate } & \multicolumn{3}{|c|}{ Ammonia } & \multicolumn{3}{|c|}{ Fecal Coliform } \\
\hline & OV & MR & $\mathrm{X}^{2}$ & OV & MR & $\mathrm{X}^{2}$ & OV & MR & $\mathrm{X}^{2}$ & OV & MR & $X^{2}$ & OV & MR & $\mathbf{X}^{2}$ \\
\hline 12.94 & 28.83 & 28.83 & 0 & 628 & 628 & 0.00 & 20.833 & 20.883 & 0.12 & 18.6 & 19 & 0.01 & 220 & 220 & 0.00 \\
\hline 10.08 & 22.7 & 21.27 & 0.09 & 725.4 & 722 & 0.02 & 21.579 & 21.597 & 0.02 & 18.04 & 18 & 0.00 & 278.46 & 283.3 & 0.08 \\
\hline 7.71 & 18.96 & 18.27 & 0.03 & 882.7 & 870 & 0.18 & 22.606 & 22.633 & 0.03 & 35.28 & 37 & 0.08 & 284.89 & 283.3 & 0.01 \\
\hline 3.6 & 13.63 & 12.43 & 0.11 & 1062 & 1053 & 0.08 & 16.274 & 16.230 & 0.12 & 34.78 & 35 & 0.00 & 189.35 & 190 & 0.00 \\
\hline \multirow[t]{4}{*}{0} & 9.47 & 10 & 0.03 & 917 & 931 & 0.21 & 23.492 & 23.487 & 0.00 & 218.8 & 212 & 0.21 & 295.69 & 303.3 & 0.20 \\
\hline & \multicolumn{2}{|c|}{ Rata-rata } & 0.05 & \multicolumn{2}{|c|}{ Rata-rata } & 0.10 & \multicolumn{2}{|c|}{ Rata-rata } & 0.06 & \multicolumn{2}{|c|}{ Rata-rata } & 0.06 & Rata-ra & & 0.06 \\
\hline & Total & & 0.25 & Total & & 0.49 & Total & & 0.29 & Total & & 0.31 & Total & & 0.29 \\
\hline & Model & literima & & odel dit & rima & & Model d & iterima & & Model & diteri & & Model & iterima & \\
\hline
\end{tabular}

Keterangan: OV = hasil observasi; $\mathrm{MR}=$ hasil model 


\section{Penentuan Indeks Pencemar}

Perhitungan indeks pencemar menunjukkan seberapa banyak polutan yang masuk ke dalam badan air. Hasil perhitungan menunjukkan bahwa terdapat 10 lokasi sampling yang memiliki status pencemaran ringan kecuali lokasi sampling keenam dan lokasi 10 dengan status pencemaran sedang (Tabel 5). Lokasi pengambilan sampling keenam menjadi lokasi yang paling banyak menerima polutan sehingga beberapa parameter melebihi bakumutu dan memiliki status mutu paling besar dibandingkan lokasi yang lain.

Tabel 5. Hasil Perhitungan Indeks Pencemaran

\begin{tabular}{ccl}
\hline Lokasi Sampling & $\begin{array}{c}\text { Indeks } \\
\text { Pencemaran }\end{array}$ & \multicolumn{1}{c}{ Status Mutu Air } \\
\hline 1 & 2.93 & cemar ringan \\
2 & 2.74 & cemar ringan \\
3 & 2.87 & cemar ringan \\
4 & 3.38 & cemar ringan \\
5 & 3.09 & cemar ringan \\
6 & 8.23 & cemar sedang \\
7 & 3.25 & cemar ringan \\
8 & 3.44 & cemar ringan \\
9 & 2.63 & cemar ringan \\
10 & 6.05 & cemar sedang \\
11 & 3.62 & cemar ringan \\
12 & 2.34 & cemar ringan \\
\hline
\end{tabular}

Pada lokasi sampling pertama, kedua, ketiga, kelima, ketujuh, dan kedelapan parameter yang melebihi bakumutu adalah BOD, Nitrat, ammonia dan phosphate. Sedangkan pada lokasi keempat dan kesebelas terdapat lima parameter yang melampui standar kelas air II adalah BOD, COD, Nitrat, ammonia dan phosphate. Lokasi keenam parameter yang melebihi baku mutu adalah BOD, COD, ammonia dan phosphate, lokasi kesembilan parameter yang melebihi baku mutu adalah BOD, COD, TSS. Nitrat dan Phosphat, lokasi kesepuluh dan keduabelas parameter yang melebihi BOD, Nitrat, phosphate.

\section{Penentuan Beban Pencemaran}

Berdasarkan hasil perhitungan beban pencemaran actual pada keseluruhan lokasi, lokasi pertama sudah tidak mampu lagi menerima beban pencemar dengan konsentrasi BOD, Nitrat, ammonia dan phosphate. Rata-rata beban pencemar yang diterima oleh lokasi pertama berkisar $25.19 \mathrm{~kg}$ /hari sedangkan batas maksimal beban pencemar yang diterima sebesar $32.32 \mathrm{~kg} /$ hari, sehingga secara keseluruhan masih bisa menerima beban pencemar namun untuk beberapa parameter yang lain sudah melampui baku mutu sebagai contoh parameter BOD dengan $11.8 \mathrm{~kg} /$ hari konsentrasi BOD yang berlebihan bagi perairan, 24.69 $\mathrm{kg} /$ hari untuk parameter Nitrat, $0.04 \mathrm{~kg} / \mathrm{hari}$ untuk konsentrasi ammonia, dan $1.77 \mathrm{~kg} / \mathrm{hari}$ untuk konsentrasi phosphate. Lokasi titik pengambilan lokasi pertama berada dekat dengan industri rumah sakit. Sehingga, pada titik ini pencemar disebabkan oleh kegiatan pembuangan limbah industri rumah sakit. Pada hasil perhitungan DTBP pembuangan limbah industri rumah sakit menyebabkan terlampauinya daya tampung beban pencemaran pada parameter BOD, nitrat, amonia dan fosfat. Hal ini perlu perhatian dari pemerintah untuk memantau kegiatan rumah sakit. Pengolahan limbah cair rumah sakit 
yang ada pada daerah ini harus dipantau, bagaimana hasil keluaran yang dibuang ke sungai. Karena sebelum dibuang ke sungai, konsentrasi pencemar yang ada harus diolah terlebih dahulu agar memenuhi baku mutu yang diperbolehkan terutama pada parameter BOD, nitrat, amonia dan fosfat. Selain pemantauan, kegiatan yang dapat dilakukan untuk menurunkan beban adalah pembinaan, yaitu dalam program Program Kali Bersih (PROKASIH) sesuai dengan Peraturan Menteri Negara Lingkungan Hidup Nomor 01 Tahun 2010 Tentang Tata Laksana Pengendalian Pencemaran Air.

Lokasi kedua memiliki beban pencemar yang lebih rendah dibandingkan dengan lokasi pertama dengan rata-rata beban pencemar yang diterima secara keseluruhan 8.63 $\mathrm{kg} /$ hari dan konsentrasi maksimum yang diterima sebesar $11.09 \mathrm{~kg} /$ hari. Parameter yang diterima berlebih di lokasi ini adalah BOD dengan konsentrasi yang diterima melebihi 4.1 $\mathrm{kg} /$ hari, sedangkan nitrat berlebih sebesar $7.82 \mathrm{~kg} / \mathrm{hari}$ ammonia $0.02 \mathrm{~kg} / \mathrm{hari}$ dan phosphate sebesar $0.59 \mathrm{~kg} /$ hari. Lokasi kedua menerima beban pencemar dari limbah domestik dan rumah sakit. Titik 2 berada pada daerah dekat dengan industri, rumah sakit dan pemukiman seperti pada titik sebelumnya. Penyebab terlampauinya daya tampung pada parameter BOD, nitrat dan fosfat akibat dari limbah industri dan rumah sakit. Pembuangan limbah perlu dilakukan pemantauan yang lebih karena apabila dibiarkan secara terus-menerus akan mengalami akumulasi yang meningkat setiap harinya dan daya tampung akan mengalami penurunan sehingga akan memperburuk kondisi yang ada.

Parameter yang melampaui DTBP pada lokasi ketiga yaitu yaitu BOD, nitrat dan fosfat. Kelebihan DTBP yang dihasilkan lebih kecil dari titik sebelumnya, lokasi pengambilan berada dekat dengan pemukiman sehingga faktor yang mempengaruhi yaitu limbah domestik hasil dari kegiatan masyarakat yang ada di sekitar perairan. Daya tampung yang dihasilkan dari perhitungan sangat kecil dan nilai maksimum berada pada TSS yaitu $2.49 \mathrm{Kg} /$ hari. Hal ini dapat terjadi karena kegiatan yang ada tidak begitu signifikan merubah kualitas air sekitarnya. Tetapi, walaupun demikian perlu perhatian khusus agar tidak memperburuk yang sudah ada. Pemerintah melakukan program untuk penurunan beban pencemar untuk kegiatan domestik sebagai upaya pengelolaan daya tampung sungai. Program yang diterapkan yaitu penerapan penyediaan IPAL (Instalasi Pengolahan Air Limbah) Komunal.

Pada titik pengambilan keempat terdapat di kawasan Rumah Sakit Syaiful Anwar Kota Malang, sumber pencemar berasal dari kegiatan rumah sakit. Parameter yang berlebih adalah parameter BOD, nitrat, ammonia dan fosfat. Angka hasil perhitungan yang terdapat pada tabel lebih besar dibandingkan titik sebelumnya, pada titik sebelumnya nilai maksimum pada angka 2 dan pada titik ini angka maksimum sebesar $55.36 \mathrm{Kg} / \mathrm{hari}$ pada parameter TSS. Hal ini menujukkan daya tampung TSS yang ada masih memenuhi kondisi yang seharusnya, tetapi pada parameter nitrat daya tampung yang telampaui sebesar 22.3 $\mathrm{Kg} /$ hari. Perlu adanya perhatian khusus dari daya tampung yang dihasilkan agar kedepannya tidak lebih buruk, dan solusi untuk menanggulanginya. Kegiatan rumah sakit dan pemukiman yang ada di sekitar perairan sangat mempengaruhi daya tampung perairan, maka dari itu perlu adanya peninjauan terhadap limbah yang dibuang.

Pada titik pengambilan sampel kelima ini bersumber dari industri cat dan limbah domestik warga sekitar. Lokasi pengambilan dan kegiatan yang ada disekitar perairan dapat mempengaruhi yaitu berasal dari limbah domestik dan limbah industri hasil dari kegiatan masyarakat yang ada di sekitar perairan. Daya tampung yang terlampaui paling besar yaitu pada parameter nitrat sebesar $4.02 \mathrm{Kg} /$ hari. Kegiatan yang mencemari pada titik ini yaitu industri cat dan limbah domestik. Pada PERMENLH No. 01 Tahun 2010 Tentang Tata Laksana Pengendalian Pencemaran Air, sama seperti titik sebelumnya program yang dilakukan yaitu PROKASIH dengan dua macam kegiatan yang berbeda. Kegiatan domestik untuk menurunkan beban pencemar dilakukan kegiatan pembinaan dan penyediaan IPAL Komunal. 
Lokasi keenam merupakan lokasi dengan kualitas air paling buruk dikarenakan lokasi tersebut merupakan akumulasi beban pencemaran dari industri rokok. Hal ini mempengaruhi daya tampung karena pencemaran dari buangan limbah industri rokok tersebut. Angka daya tampung yang terlampaui paling besar pada parameter COD sebesar $256,79 \mathrm{Kg} /$ hari. Perlu perhatian khusus untuk pembuangan limbah yang ada di perairan pada titik 6 agar dapat ditanggulangi dengan cepat dan tidak memperburuk kondisi yang ada. Keseluruhan hasil perhitungan beban pencemaran dapat dilihat pada Tabel 6 .

Tabel 6. Hasil Perhitungan Beban Pencemaran dan Daya Tampung Beban Pencemaran

\begin{tabular}{|c|c|c|c|c|c|c|c|c|}
\hline Lokasi & Variabel & DO & BOD & COD & TSS & $\begin{array}{l}\text { Nitrat } \\
\text { (NO3) }\end{array}$ & $\begin{array}{c}\text { Ammonia } \\
\text { (NH3) }\end{array}$ & $\begin{array}{c}\text { Phospat } \\
\text { Terlarut } \\
\text { (PO4) }\end{array}$ \\
\hline \multirow{3}{*}{1} & BPA & 9.81 & 7.36 & 61.34 & 122.68 & 24.54 & 0.05 & 0.49 \\
\hline & ВРM & 12.23 & 19.73 & 52.24 & 81.28 & 57.17 & 0.11 & 1.68 \\
\hline & DTBP & -2.42 & -12.36 & 9.09 & 41.39 & -32.63 & -0.06 & -1.19 \\
\hline \multirow{3}{*}{2} & BPA & 3.37 & 2.53 & 21.04 & 42.09 & 8.42 & 0.02 & 0.17 \\
\hline & BPM & 3.93 & 6.97 & 19.37 & 22.61 & 17.34 & 0.02 & 0.54 \\
\hline & DTBP & -0.56 & -4.44 & 1.67 & 19.48 & -8.92 & 0.00 & -0.37 \\
\hline \multirow{3}{*}{3} & BPA & 0.33 & 0.25 & 2.09 & 4.18 & 0.84 & 0.00 & 0.02 \\
\hline & BPM & 0.48 & 0.68 & 1.92 & 1.7 & 1.81 & 0.00 & 0.06 \\
\hline & DTBP & -0.14 & -0.43 & 0.17 & 2.49 & -0.97 & 0.00 & -0.04 \\
\hline \multirow{3}{*}{4} & BPA & 7.09 & 5.32 & 44.34 & 88.68 & 17.74 & 0.04 & 0.34 \\
\hline & BPM & 8.73 & 14.54 & 41.11 & 33.32 & 40.09 & 0.06 & 1.53 \\
\hline & DTBP & -1.64 & -9.22 & 3.23 & 55.36 & -22.35 & -0.02 & -1.17 \\
\hline \multirow{3}{*}{5} & BPA & 1.74 & 1.30 & 10.85 & 21.7 & 4.34 & 0.01 & 0.09 \\
\hline & ВРM & 2.66 & 3.60 & 10.11 & 3.49 & 8.36 & 0.02 & 0.17 \\
\hline & DTBP & -0.93 & -2.30 & 0.74 & 18.21 & -4.02 & -0.01 & -0.09 \\
\hline \multirow{3}{*}{6} & BPA & 13.18 & 9.88 & 82.37 & 164.74 & 32.95 & 0.07 & 0.66 \\
\hline & BPM & 3.46 & 126.47 & 339.16 & 61.75 & 9.07 & 6.72 & 5.39 \\
\hline & DTBP & 9.72 & -116.59 & -256.79 & 102.99 & 23.88 & -6.66 & -4.73 \\
\hline \multirow{3}{*}{7} & BPA & 38.53 & 28.90 & 240.81 & 481.63 & 96.33 & 0.19 & 1.93 \\
\hline & BPM & 46.93 & 75.46 & 208.36 & 162.58 & 188.98 & 0.42 & 8.84 \\
\hline & DTBP & -8.40 & -46.46 & 32.46 & 319.04 & -92.66 & -0.23 & -6.29 \\
\hline \multirow{3}{*}{8} & BPA & 4.65 & 3.48 & 29.03 & 58.07 & 11.61 & 0.02 & 0.23 \\
\hline & ВРM & 5.28 & 8.52 & 24.06 & 13.84 & 18.56 & 0.04 & 1.21 \\
\hline & DTBP & -0.63 & -5.04 & 4.97 & 44.23 & -6.94 & -0.02 & -0.98 \\
\hline \multirow{3}{*}{9} & BPA & 48.46 & 36.34 & 302.86 & 605.71 & 121.14 & 0.24 & 2.42 \\
\hline & BPM & 79.45 & 112.66 & 335.31 & 573.39 & 205.20 & 0.22 & 3.56 \\
\hline & DTBP & -30.99 & -76.31 & -32.45 & 32.32 & -84.06 & 0.02 & -1.14 \\
\hline \multirow{3}{*}{10} & BPA & 1.51 & 1.13 & 9.43 & 18.85 & 3.77 & 0.01 & 0.08 \\
\hline & BPM & 1.79 & 2.79 & 8.27 & 4.76 & 8.84 & 0.05 & 0.35 \\
\hline & DTBP & -0.29 & -1.66 & 1.16 & 14.09 & -5.07 & -0.04 & -0.28 \\
\hline \multirow{3}{*}{11} & BPA & 18.95 & 14.22 & 118.47 & 236.94 & 47.39 & 0.09 & 0.95 \\
\hline & BPM & 21.94 & 33.02 & 91.23 & 54.5 & 58.66 & 0.29 & 5.50 \\
\hline & DTBP & -2.99 & -18.81 & 27.24 & 182.44 & -11.28 & -0.19 & -4.55 \\
\hline \multirow{3}{*}{12} & BPA & 22.10 & 16.57 & 138.11 & 276.21 & 55.24 & 0.11 & 1.10 \\
\hline & BPM & 36.31 & 43.20 & 115.75 & 35.14 & 144.56 & 0.10 & 1.81 \\
\hline & DTBP & -14.21 & -26.63 & 22.35 & 241.07 & -89.32 & 0.01 & -0.71 \\
\hline
\end{tabular}

Keterangan: (-) menunjukkan beban pencemaran terlampui

Pada titik ketujuh ini serupa dengan titik sebelumnya yaitu dekat dengan industri rokok. Hal ini dapat mempengaruhi daya tampung karena pencemaran dari buangan limbah industri rokok tersebut. Angka daya tampung yang terlampaui paling besar pada parameter nitrat sebesar $92.66 \mathrm{Kg} /$ hari. Angka tersebut jumlahnya lebih kecil dibandingkan dengan titik sebelumnya. Lokasi kedelapan merupakan lokasi yang menerima beban 


\section{Penentuan Indeks Pencemaran Air dan Daya Tampung Beban Pencemaran ...}

pencemar dengan dominasi dari aktivitas rumah sakit, terdapat 3 rumah sakit yang berpotensi membuang limbah di daerah ini. Rata-rata beban yang diterima oleh lokasi ini sebesar $11.95 \mathrm{~kg} /$ hari dan rata-rata beban maksimum yang diterima sebesar $15.3 \mathrm{~kg} / \mathrm{hari}$. Parameter yang berlebih dikonsentrasi air adalah BOD dengan nilai $5.04 \mathrm{~kg} / \mathrm{hari}$, nitrat sebesar $6.94 \mathrm{~kg} / \mathrm{hari}$, ammonia sebesar $0.02 \mathrm{~kg} / \mathrm{hari}$ dan phosphate sebesar $0.98 \mathrm{~kg} / \mathrm{hari}$.

Lokasi pengambilan kesembilan berada pada daerah persawahan dan perkebunan. Hasil dari perhitungan daya tampung yang terlampaui paling besar yaitu pada parameter nitrat sebesar $84.059 \mathrm{~kg} / \mathrm{hari}$ dan BOD sebesar $76.313 \mathrm{~kg} / \mathrm{hari}$. Kegiatan yang menyebabkan nilai yang dihasilkan cukup besar karena sedikit pengaruh dari kegiatan masyarakat. Kegiatan perkebunan dan persawahan dapat menghasilkan nitrat yang cukup tinggi. Nitrat yang tinggi dapat berdampak buruk bagi kondisi perairan, maka dari itu perlu perhatian khusus dari limbah yang dihasilkan pada kegiatan masyarakat tersebut. Pada PERMENLH No. 01 Tahun 2010 Tentang Tata Laksana Pengendalian Pencemaran Air, penurunan beban pencemar dapat dilakukan untuk kegiatan pertanian yaitu dengan program Green Farming. Kegiatan yang dilakukan untuk mendukung program penurunan beban pencemar yaitu pembinaan dan penyuluhan.

Lokasi titik ini diambil dekat dengan Pasar Gadang yang sumber pencemarnya yang dihasilkan diperoleh dari limbah domestik yang dihasilkan pasar dan terdapat rumah sakit, karena kegiatan yang memengaruhi tidak terlalu signifikan maka hasil daya tampung terlampaui cukup kecil. Parameter yang memiliki daya tampung terlampaui paling besar pada parameter nitrat sebesar $5.074 \mathrm{Kg} /$ hari. Hal ini perlu perhatian khusus dan tidak boleh dianggap remeh. Pada titik 11 berada pada lokasi daerah industri dari beberapa rumah sakit. Limbah dari industri rumah sakit dapat mempengaruhi daya tampung yang dihasilkan. Nilai daya tampung yang terlampaui paling tinggi pada parameter BOD sebesar $18.81 \mathrm{Kg} /$ hari. Hal ini menunjukkan bahwa dampak dari industri rumah sakit dapat menyebabkan telampauinya beberapa parameter di antaranya BOD, nitrat, amonia, dan fosfat. Perlu perhatian khusus agar tidak memperburuk kondisi daya tampung yang ada di perairan. Lokasi pengambilan pada titik keduabelas berada di daerah Bandulan, hasil perhitungan daya tampung beban pencemaran (DTBP) didapatkan beberapa parameter yang menghasilkan nilai negatif di antaranya parameter DO, BOD, nitrat, amonia, dan fosfat. Penggunaan model QUAL2Kw dapat digunakan pada pemantauan kualitas air sungai dari sumber pencemar point source dan nonpoint source namun dengan tingkat kesalahan mencapai 30\%. Hal ini dipengaruhi penggunaan nonpoint source pada simulasi menggunakan QUAL2Kw, apabila dibandingkan dengan simulasi menggunakan point source dengan kesalahan yang dihasilkan $21.16 \%$ (Fajaruddin et al., 2018), maka kesalahan tersebut relatif lebih besar.

\section{Kesimpulan}

Terdapat dua jenis tingkat pencemaran di Sungai Brantas Kota Malang yaitu sepuluh lokasi dengan tingkat pencemaran ringan dan dua lokasi tercemar sedang. Hasil simulasi kualitas air sungai Brantas Kota Malang menggunakan QUAL2Kw menunjukkan bahwa pola konsentrasi BOD, COD, TSS, ammonia, nitrat, dari hulu ke hilir memiliki pola kecenderungan yang relatif meningkat, sedangkan konsentrasi $\mathrm{pH}$, phosphate dan konsentrasi total coliform menunjukkan pola yang berbeda yaitu semakin ke hilir menunjukkan penurunan. Beban pencemaran di Sungai Brantas dengan konsentrasi yang berlebih adalah BOD, COD, Ammonia, Nitrat dan Phosphat.

Hasil penilaian kualitas air Sungai Brantas ini dapat menjadi pertimbangan bagi pemangku kepentingan dalam membatasi jumlah limbah cair yang dibuang ke Sungai Brantas, sebagai pertimbangan dalam menginisiasi pengolahan limbah cair yang efektif dari sumber aktivitas industri, rumah sakit dan domestik serta menginisiasi pemusatan lokasi 
untuk kegiatan yang berkontribusi dalam pencemaran Sungai Brantas yang dilengkapi dengan fasilitas pengolahan limbah cair.

\section{Daftar Pustaka}

Abler, D. (2015). Economic evaluation of agricultural pollution control options for China. Journal of Integrative Agriculture, 14(6), 1045-1056. doi:10.1016/S2095-3119(14)60988-6.

Arief, A. M., Haribowo, R., \& Yuliani, E. (2017). Studi penentuan daya tampung beban pencemaran Hulu Sungai Brantas ruas Temas-Dadaprejo Kota Batu dengan menggunakan aplikasi QUAL2KW. Universitas Brawijaya.

Bjornn, Tc., \& Reiser, D. W. (1991). Habitat requirements of salmonids in streams. American Fisheries Society Special Publication, 19(837), 83-138.

BPS Kota Malang. (2018). Kota Malang dalam Angka 2018.

Damanik, Janianton; Weber, H. (2006). Perencanaan ekowisata dari teori ke aplikasi. Yogyakarta: PUSPAR UGM dan ANDI.

Emmanuel, E., Perrodin, Y., Keck, G., Blanchard, J.-M., \& Vermande, P. (2005). Ecotoxicological risk assessment of hospital wastewater: a proposed framework for raw effluents discharging into urban sewer network. Journal of Hazardous Materials, 1171), 1-11. doi:10.1016/j.jhazmat.2004.08.032.

Fajaruddin, A. H., Sholichin, M., \& Prayogo, T. B. (2018). Studi penentuan daya tampung beban pencemaran Sungai Brantas ruas Kota Malang dengan menggunakan paket program Qual2KW. Universitas Brawijaya.

Hodgson, S., \& Quinn, T. P. (2002). The timing of adult sockeye salmon migration into fresh water: adaptations by populations to prevailing thermal regimes. Canadian Journal of Zoology, 80(3), 542-555. doi:10.1139/z02-030.

Kementrian Lingkungan Hidup. (2003). Pedoman penetapan daya tampung beban pencemaran air pada sumber air. Jakarta.

Lee, R. M., \& Rinne, J. N. (1980). Critical thermal maxima of five trout species in the southwestern United States. Transactions of the American Fisheries Society, 1096), 632-635. doi:10.1577/15488659(1980)109<632:CTMOFT>2.0.CO;2.

Line, D. E., Harman, W. A., Jennings, G. D., Thompson, E. J., \& Osmond, D. L. (2000). Nonpoint- source pollutant load reductions associated with livestock exclusion. Journal of Environmental Quality, 29(6), 1882-1890. doi:10.2134/jeq2000.00472425002900060022x.

Lund, S. G., Caissie, D., Cunjak, R. A., Vijayan, M. M., \& Tufts, B. L. (2002). The effects of environmental heat stress on heat-shock mRNA and protein expression in Miramichi Atlantic salmon ( Salmo salar ) parr. Canadian Journal of Fisheries and Aquatic Sciences, 599), 1553-1562. doi:10.1139/f02-117.

Mahmud, M. (2014). Kajian pencemaran merkuri terhadap lingkungan di Kabupaten Gorontalo Utara. Penelitian Kerjasama (Pemda, BUMD/N, Swasta). Pusat Studi Lingkungan Hidup dan Kependudukan, Universitas Negeri Gorontalo.

Mohseni, O., \& Stefan, H. G. (1999). Stream temperature/air temperature relationship: a physical interpretation. Journal of Hydrology, 218(3-4), 128-141. doi:10.1016/S0022-1694(99)00034-7.

Neal, C., Williams, R. J., Neal, M., Bhardwaj, L. C., Wickham, H., Harrow, M., \& Hill, L. K. (2000). The water quality of the River Thames at a rural site downstream of Oxford. Science of The Total Environment, 251-252, 441-457. doi:10.1016/S0048-9697(00)00398-3.

Patricia, C., Astono, W., \& Hendrawan, D. I. (2018). Kandungan nitrat dan fosfat di Sungai Ciliwung. In Prosiding Seminar Nasional Cendekiawan (pp. 179-185).

Pelletier, G., \& Chapra, S. (2006). A modeling framework for simulating river and stream water quality. Environmental Assessment Program: Olympia, Washington, 97710-98504.

Pemerintah Republik Indonesia. (2001). Peraturan Pemerintah Republik Indonesia nomor 82 tahun 2001 tentang pengelolaan kualitas air dan pengendalian pencemaran air. Retrieved from https://peraturan.bpk.go.id/Home/Details/53103/pp-no-82-tahun-2001.

Salem, Z., Toumi, L., Kechroud, Y., \& Allia, K. (2007). Evaluation of hospital wastewaters pollution and treatment recommendations. In Proceedings of the 10th International Conference on Environmental 


\section{Penentuan Indeks Pencemaran Air dan Daya Tampung Beban Pencemaran ...}

Science and Technology Greece.

Sammana, I. A. (2006). Keberadaan unsur hara dalam media air laut bersubstrat zeocrete pada tingkat konsentrasi $P$ berbeda. Institut Pertanian Bogor.

Samudro, S., Agustiningsih, D., \& Sasongko, S. B. (2012). Analisis kualitas air dan strategi pengendalian pencemaran air Sungai Blukar Kabupaten Kendal. Jurnal Presipitasi: Media Komunikasi dan Pengembangan Teknik Lingkungan, 9(2), 64-71. doi:10.14710/presipitasi.v9i2.64-71.

Spalding, R. F., \& Exner, M. E. (1993). Occurrence of nitrate in groundwater-a review. Journal of Environmental Quality, 22(3), 392-402. doi:10.2134/jeq1993.00472425002200030002x.

Sun, B., Zhang, L., Yang, L., Zhang, F., Norse, D., \& Zhu, Z. (2012). Agricultural non-point source pollution in China: Causes and mitigation measures. AMBIO A Journal of the Human Environment, 41(4), 370-379. doi:10.1007/s13280-012-0249-.

Wang, H., Gao, J., Li, X., Zhang, S., \& Wang, H. (2015). Nitrate accumulation and leaching in surface and ground water based on simulated rainfall experiments. PLoS One, 19(8), e0136274. doi:10.1371/journal.pone.0136274.

Webb, B. W. (1996). Trends in stream and river temperature. Hydrological Processes, 19(2), 205-226. doi:10.1002/(SICI)1099-1085(199602)10:2<205::AID-HYP358>3.0.CO;2-1.

Webb, B. W., \& Walsh, A. J. (2004). Changing UK river temperatures and their impact on fish populations. Hydrology: Science \& Practice for 21st Century, 2, 177-191.

Yetti, E., Soedharma, D., \& Hariyadi, S. (2011). Evaluasi kualitas air sungai-sungai di kawasan DAS brantas hulu Malang dalam kaitannya dengan tata guna lahan dan aktivitas masyarakat di sekitarnya. Jurnal Pengelolaan Sumberdaya Alam dan Lingkungan, 1(1), 10-15. doi:10.29244/jpsl.1.1.10.

Yuliati, U. (2013). Faktor-faktor yang mempengaruhi konsumen dalam pembelian makanan jajan tradisional di Kota Malang. Manajemen Bisnis, 1(1), 7-20.

Zahroh, A., Riani, E., \& Anwar, S. (2019). Analisis kualitas perairan untuk budidaya kerang hijau di Kabupaten Cirebon Provinsi Jawa Barat. Jurnal Pengelolaan Sumberdaya Alam dan Lingkungan, 9(1), 86-91. doi:10.29244/jpsl.9.1.86-91. 